\title{
Vocational School Students With Five-Factor Model of Personality Determination of Personality Profile*
}

\author{
Mısırdalı Yangil Fulya, Baş Metin, Fırın Sevcan \\ Dumlupınar University, Kütahya, Turkey
}

\begin{abstract}
Personality refers to the integration of feelings, thoughts, and behaviors specific to individual. The fact that personality has a distinguishing feature among individuals explains different behaviors of individuals against events and situations. This arises from the fact that personality is specific to individual and is affected by the effects of many factors with which it interacts, and from the integration of them. In this context, this research is based on the hypothesis that there is a relationship between vocational school students' demographic features including their family, socio-culture, geographical environments (gender, age, department, grade, parental education, number of siblings, birth order in the family, and the family's income levels), and the personality profiles. The research was carried out as part of five-factor model of personality in an attempt to determine whether vocational school students' personality profiles vary according to demographic variables and to reveal the relationship between them. The research sample consisted of 220 students selected from the students studying in Altıntaş Vocational School in the Spring Term of the 2013-2014 Academic Year. Data were analyzed via SPSS 15.0 statistical package program by performing $t$-test, analysis of variance and logistic regression analysis. While a significant difference was found between students' five-factor personality profiles according to gender, age, department, average, father's education, and the number of siblings, no significant difference was found among grade, mother's education, birth order in the family, and income levels. Moreover, independent variables affecting students' academic averages were determined as a result of the logistic regression analysis.
\end{abstract}

Keywords: personality, personality characteristics, five-factor model of personality, analysis of variance, logistic regression

\section{Introduction}

Organizational behavior discipline examines the causes and consequences of individual's all behaviors within the organization in a holistic manner. Also, the concept of personality is included in the organizational behavior discipline as a key issue and has been intensively examined in academic studies in recent times. The reason for this interest in academic studies is the fact that the concept of personality addresses the whole behavioral, emotional, and cognitive aspects of individuals and also affects these factors being influenced by

\footnotetext{
* The article's abstract was presented at the 16th International Symposium on Economics, Operation Research and Statistics on May 7-12, 2015.

Mısırdalı Yangil Fulya, asst. prof., Department of Management and Organization, Dumlupınar University, Kütahya, Turkey.

Baş Metin, asst. prof., Department of Econometrics, Dumlupınar University, Kütahya, Turkey.

Fırın Sevcan, lecturer, Department of Management and Organization, Dumlupınar University, Kütahya, Turkey.

Correspondence concerning this article should be addressed to Mısırdalı Yangil Fulya, Dumlupınar University, Altıntaş Vocational School, Altıntaş, Kütahya, Turkey.
} 
the factors around the individual. Therefore, personality comprises a structure that originates from the genetic and biological characteristics of the individual and then interacts with his/her social environment. By this structure, personality is a concept that focuses on individuals' differences beyond their similarities. In this context, it can be said that the holistic structure of personality is an important factor that determines the future of the individual. The self-knowledge level of the individual, in other words, individual's awareness regarding his/her characteristics is a factor affecting the quality of his/her preferences in the present and future life and thereby the quality of life.

Professional competence and the professional success depend upon the harmony between individual's personality characteristics and the profession he/she prefers. Therefore, an individual should know his/her own characteristics before determining the profession. In other words, individuals should know their own personality characteristics to ensure compliance between business and personality and to be able to complete future career development. Thus, individuals will be able to recognize themselves and to reveal for which professional groups their personality characteristics are compatible.

This research is based on the hypothesis that there is a relationship between vocational school students' demographic features including their family and socio-cultural environments and the personality profiles. The research was carried out as part of five-factor model of personality in an attempt to determine whether vocational school students' personality profiles vary according to demographic variables and to reveal the relationship between them. For this purpose, answers were sought for the following questions:

(1) What levels are the personality dimensions of students studying in the Vocational School? Which of the five-factor personality dimensions is at the higher level?

(2) Do Vocational School students' personality profiles vary according to demographic variables?

(3) From which independent variables are Vocational School students' academic achievements affected?

This research is essential in terms of determining students' personality profiles. Thus, by this research, students will be supported to recognize themselves and in this context, benefits will be provided to increase their satisfaction and success levels both in their professional and social lives.

\section{Literature Review}

\section{The Concept of Personality}

Scientific development of the concept of personality dates back to 1930s. During those years, psychology of personality emerged as a separate discipline from other social sciences (Mc Adams, 1997, p. 4). Personality is the complement of qualities in which the causes of human behavior are formed by the constant emotional, cognitive, and behavioral structures in time by getting together (Mount, Barrick, Scullen, \& Rounds, 2005, p. 448). Personality is an organized structure by this definition. Elements of this structure are in constant relationship with each other and have a feature of affecting and complementing each other (Sarıtaş, 1997, $p$. 529; Güvenç, 1972, p. 347).

The concept of personality can be identified by two different aspects. The first one is related to how individuals are perceived by the people outside. In this context, it is concluded that the concept of personality of the individual has a social aspect. The second one is related to individual's own individual characteristics. These characteristics represent the consistent behavior models exhibited by the individual in the face of a certain event or situation (Hogan, 1991, p. 874). In addition, the concept of personality includes different and generalizable characteristics of the individual. When it is evaluated in this context, personality has also two 
aspects based on individual distinguishing and generic characteristics (Sarıtaş, 1997, p. 528). Factors that are effective in the formation of personality are also effective in the formation of distinguishing characteristics and generic characteristics. These factors can be sorted as genetic, family, group memberships, socio-cultural structure, social class, geographical and physical characteristics, mass publishing tools, and birth order (Barl, 2008, pp. 80-83).

Personality has some key features. These are (Barl1, 2008, p. 83):

- Personality is the sum of both genetic and acquired features.

- Some attitudes and behaviors are a part of personality.

- Psychological and physical structure of the individual constitutes an important part of the personality.

- A large number of factors such as genetic factors, family, and social environment play role in the formation and development of personality.

- A particular feature should be consistent and continuous to be defined as a part of personality.

- Personality is a complex concept with abstract and concrete features.

- The personality of an individual is specific to him/her, thus personality is an important factor that distinguishes individuals from each other.

The concept of personality has a vital role in psychological science in terms of being able to explain the meaning of and predict individual's thoughts and feelings. However, in addition to this, it also affects the assessment of the characteristics of the organization member included within the organization such as organizational loyalty, creativity characteristics, sense of competition, and predisposition to teamwork (Nelson, 2011, p. 15). In this context, determination or recognition of individual's personality characteristics at the stage of participation to the organization could affect the individual and organizational performance.

\section{The Five-Factor Model of Personality}

Numerous scales have been developed in the literature for the determination of personality characteristics. One of these scales is the "International Personality Inventory". Five-factor model of personality was developed as a result of this scale. Researchers who perform studies on personality focused on the five-factor model of personality to regulate approaches addressing personality in a wider context and to make it more meaningful by eliminating confusion in the literature on this subject (Ökten \& Cenkci, 2013, p. 43). Five-factor model of personality allows individual to identify himself/herself and other individuals based on the adjectives in the word. In this context, five sub-dimensions in the five-factor model of personality were revealed for the experimental investigation of the personality (Goldberg, 1993, pp. 26-34). Due to the fact that five-factor model of personality is the most basic and most advanced model established for the human personality within academic and all main branches of applied psychology (Gill \& Hodgkinson, 2007, p. 735), it has maintained its place as the most widely used model since 1980s (Costa \& McCrae, 1995, p. 22; Goldberg, Johnson, Eber, Hogan, Ashton, Cloninger, \& Gough, 2006, p. 84; Tozkoparan, 2013, p. 197).

Five-factor model of personality is commonly known by the dimensions of "Extraversion", "Openness to Improvement", "Emotional Balance", "Compliance", and "Responsibility" (Mount, Ilies, \& Johnson, 2006, p. 595). According to Goldberg (1992), the dimension of extroversion represents characteristics such as loving to be with people, loving entertainment, leadership, power, being ambitious, and behaving friendly (Somer, Korkmaz, \& Tatar, 2002, p. 23). The dimension of openness to improvement includes characteristics of the people such as being sensitive, flexible, creative, cultured, intellectual and artistic in thinking, and provides functional benefits 
by their creativity (Tatlllığlu, 2014, p. 948). Being openness to experience or improvement that expresses creativity and cognitive complexity includes the ability to empathize in various conflict situations experienced by taking into account the opinion of the other party (Tozkoparan, 2013, p. 199). The dimension of emotional balance includes characteristics such as whether the individual is angry, the degree of self-confidence, being optimistic or pessimistic, self-conscious, emotional, and anxious (Soysal, 2008, p. 10). In the dimension of compliance, it could be said that individuals act according to the nature of their environment, and resort to find solution against any negative situation by acting moderately and calmly. In addition, this dimension comes to the forefront when it is necessary to display performance by working together with others, and thereby, it is very important in teamwork (Tozkoparan, 2013, p. 200). In the dimension of responsibility, individuals try to fulfill the given responsibility in a rigorous manner while working, and they do not keep away from taking responsibility (Merdan, 2013, p. 143). In this personality dimension, interpersonal success is high and people are careful, planned, honest, and trustworthy (Tozkoparan, 2013, p. 200).

Five-factor model of personality represents the basic dimensions of personality, and these factors are based on four key points. These are: a) longitudinal and inter-observer studies maintain the power and effect of revealing these five-factor behavior patterns for a long time; b) characteristics associated with each factor are present in the language and personality systems of the society examined; c) although these five factors are expressed differently in different cultures, these factors are present in different age, gender, race, and language groups; and d) they hereditarily indicate the biological foundations (Costa \& McCrae, 1991, p. 653). Table 1 shows the historical development of the five-factor model of personality. Accordingly, five-factor personality model studies have been carried out since 1930s.

Table 1

Names Chosen in the Historical Development in Five-Factor Model of Personality

\begin{tabular}{|l|l|}
\hline Date & Names chosen in the historical development in five-factor model of personality \\
\hline $1930 \mathrm{~s}$ & Thurstone (1934); Allport and Odbert (1936) \\
\hline $1940 \mathrm{~s}$ & Cattel (1943b, 1945); Eysenck (1947); Guilford (1948); Fiske (1949) \\
\hline $1950 \mathrm{~s}$ & Cronbach and Meehl (1955); Cattell (1957); Loevinger (1957); Guilford (1959) \\
\hline $1960 \mathrm{~s}$ & Tupes and Christal (1961);Tupes and Kaplan (1961); Norman (1963, 1967); Borgatta (1964) \\
\hline $1970 \mathrm{~s}$ & $\begin{array}{l}\text { Adcock (1972); Eysenck (1972); Cattel (1973); Hofstee (1976); Howarth (1976); Goldberg (1977); Tomas } \\
\text { (1977); Brokken (1978); Digman (1979) }\end{array}$ \\
\hline $1980 \mathrm{~s}$ & $\begin{array}{l}\text { Goldberg (1980, 1981, 1982); Digman and Takemoto-Chock (1981); John, Goldberg, and Angleitner (1984); } \\
\text { Conley (1985); Hogan (1986); Borkenau (1988); Botwin and Buss (1989); Peabody and Goldberg (1989) }\end{array}$ \\
\hline $1990 \mathrm{~s}$ & Costa and McCrae (1992a, 1992b); Judge and Cable (1997); McCrae and Costa (1999) \\
\hline
\end{tabular}

Note. Jia $(2008$, p. 31).

\section{Research Method}

\section{Aim and Importance of the Research}

Personality is specific to individuals. Personality remains under the influence of factors with which individuals interact. Along with the analysis of these factors, more successful results are obtained by the self-recognition process of the individual. Therefore, this research is important for vocational school students to act more consciously for their professional and social development by ensuring they recognize themselves better.

This research is based on the hypothesis that there is a relationship between vocational school students' 
demographic features including their family and socio-cultural environments and the personality profiles. The research was carried out as part of five-factor model of personality in an attempt to determine whether vocational school students' personality profiles vary according to demographic variables and to reveal the relationship between them. Five-factor model of personality has been the most widely used model since 1980s. Therefore, this model was used in the research.

\section{Limitations of the Research}

Students studying in Dumlupınar University Altıntaş Vocational School in the Spring Term of the 2013-2014 Academic Year were included in the scope of the research. Interpretations of the results were examined in accordance with the students involved in the research.

\section{Sample and Data Collection Tool}

The research sample consisted of 220 students selected by the simple random sampling from the students studying in Altıntaş Vocational School in the Spring Term of the 2013-2014 Academic Year. Data of the research were collected through survey method. In the determination of personality characteristics, "International Personality Inventory-IPI" consisting of 50 statements, which was developed by Goldberg (1999) as part of the International Personality Inventory Item Pool-IPIP project, was used. The survey form was executed in two main sections. First section of the survey includes 50 questions generated with ordinal five-point Likert type scale, and the second section includes 10 demographic questions (gender, age, department, grade, average, mother's education, father's education, number of siblings, birth order in the family, and level of income) generated with the nominal scale.

About 300 surveys formed to be applied to students in vocational school within the scope of the research were distributed in accordance with the course hours of the students. As a result of the application, 250 surveys were brought back by being answered, and 30 of these surveys were excluded from the research after assessment due to the large number of mistaken, incomplete, and voided questions. Thus, research results were analyzed on final 220 surveys.

\section{Findings and Research Results}

Data set compiled in the research was made suitable for the analysis in SPSS 17.0 statistical package program. In the analysis of the answers given, descriptive statistics were calculated to determine the demographic features and personality profiles. Analysis of variance was applied to reveal the differences between the demographic features of students and the personality profiles. Logistic regression analysis was used in determining the variables affecting vocational school students' academic achievements within the scope of five-factor model of personality and demographic features. Academic achievement dependent variable was taken as a two-class variable in the form of 0-1.99 and 2.00-4.00; accordingly, between 0-1.99 is academically unsuccessful and 2.00-4.00 is academically successful.

In the research, Cronbach's alpha coefficient calculated for a total of 50 questions was found to be 0.736 . The scale used was determined to be a highly reliable scale according to this value found for the questions constituting the mainframe of the scale and for the answers given.

According to Table 2, it was observed in the research carried out that the compliance dimension of vocational school students was higher compared to other dimensions according to the answers given to questions that constituted the five-factor model of personality. 
Before performing, the analysis of variance, normal distribution of the five-factor model of personality was examined by the One Sample Kolmogorov Smirnov test. Accordingly, it was observed that the dimensions of emotional balance, compliance, and openness to improvement showed normal distribution but the dimensions of extroversion and responsibility did not show a normal distribution. While analysis of variance was used in normally distributed dimensions, nonparametric equivalent was used in normally distributed dimensions.

Table 2

Five Factor Model of Personality Descriptive Statistics

\begin{tabular}{ll}
\hline Five-factor personality & Average \\
\hline Extroversion & 3.30 \\
Responsibility & 3.34 \\
Emotional balance & 3.17 \\
Compliance & 3.37 \\
Openness to improvement & 3.06 \\
\hline
\end{tabular}

Table 3

Multiple Comparison Results Table

\begin{tabular}{lllllll}
\hline & & Extroversion * & Responsibility * & $\begin{array}{l}\text { Emotional } \\
\text { balance }\end{array}$ & Compliance & $\begin{array}{l}\text { Openness to } \\
\text { improvement }\end{array}$ \\
\hline \multirow{2}{*}{ Age } & Test value & 2.509 & 2.599 & 0.227 & 0.798 & 5.646 \\
& $p$ & 0.285 & 0.273 & 0.797 & 0.452 & 0.004 \\
Department & Test value & 13.165 & 5.259 & 1.029 & 0.310 & 0.969 \\
Father's & $p$ & 0.022 & 0.385 & 0.401 & 0.907 & 0.438 \\
education & Test value & 0.307 & 2.068 & 2.659 & 0.196 & 1.870 \\
Number of & Test value & 0.594 & 0.558 & 0.049 & 0.899 & 0.136 \\
siblings & $p$ & 0.964 & 0.659 & 0.908 & 0.601 & 2.375 \\
\hline
\end{tabular}

Note. *Kruskal Wallis test results.

Table 4

Paired Comparison Results Table

\begin{tabular}{lllllll}
\hline & Extroversion ** & Responsibility ** & $\begin{array}{l}\text { Emotional } \\
\text { balance }\end{array}$ & Compliance & $\begin{array}{l}\text { Openness to } \\
\text { improvement }\end{array}$ \\
\hline Gender & $p$ & 0.211 & 0.970 & 0.386 & 0.018 & 0.005 \\
Average & $p$ & 0.534 & 0.915 & 0.836 & 0.002 & 0.492 \\
\hline
\end{tabular}

Note. **Mann Whitney $U$ test results.

According to Table 3, there is a significant difference in the students' dimension of openness to improvement by the variable of age groups. There is no significant difference in other dimensions. According to the multiple comparison test performed, it was determined that this difference resulted from the difference between 17-19 and 23-25 age groups.

There is a significant difference in the dimension of openness to improvement by the variable of the number of siblings. There is no significant difference in other dimensions. According to the comparison tests performed, this difference resulted from the difference between those with one and two siblings in the dimension of openness to improvement.

There is a significant difference in the dimension of extroversion by the variable of students' department. 
There is no difference with other dimensions. According to the comparison tests performed, this difference resulted from the difference among Department of Food Technology and Business Management and Department of Medicinal Aromatic Plants, and from the difference between Department of Food Quality Control and Department of Medicinal Aromatic Plants.

There is a significant difference in the dimension of emotional balance by the variable of father's education level. There is no difference with other dimensions. According to the comparison tests performed, it was determined that this difference resulted from the general structure.

According to Table 4, there is a significant difference in the dimensions of openness to improvement and compliance by the variable of gender. There is no difference with other dimensions. It was determined that this difference resulted from the fact that male students were at higher level compared to female students.

There is a significant difference in the dimension of compliance by the variable of academic average. There is no difference with other dimensions. It was determined that this difference resulted from the fact that students with the average of 0-1.99 were at higher level compared to students with the average of 2.00-4.00.

Whether answers to the questions given by those with an academic average of below 2 and above 2 were effective was analyzed by the logistic regression analysis. Thus, an attempt to determine the place of all questions in the demographic features and five-factor model of personality was made. According to analysis results, variable selection was made with forward stepwise technique in the model. Appropriate model selection took place in the sixth step. Thus, it was observed that at least one independent variable had effect on the dependent variable (academic averages) in the model. It was observed in the sixth step that Cox \& Snell $R^{2}=$ 0.324 and Nagelkerke $R^{2}=0.433$ value had an adequate size in the research and the model established had a power in explaining the dependent variable. The compliance of the logistics model established with data was determined by using Hosmer \& Lemeshow test. The independent variables determined in the model were the vocational school students' questions of gender, grade, and father's education, she/he does not talk a lot, she/he remains in the background, and she/he would be sad quickly. These independent variables were determined to be effective on the academic achievement.

\section{Conclusion and Suggestions}

The concept of personality which is based on individual differences is frequently discussed and analyzed in the literatures of psychology, sociology, and management. Personality addresses the individual with a holistic view and focuses on the individual's behavioral, emotional, and cognitive structure. The genetic, familial, and social features which are effective in the formation of personality cause individual to become different from other individuals, and thus it is addressed as the distinguishing characteristics of the individual. By this research, the demographic variables which are considered to be effective in the formation of personality were examined.

The research was carried out as part of five-factor model of personality in an attempt to determine whether vocational school students' personality profiles vary according to demographic variables and to reveal the statistically significant relationship between them. In light of the findings obtained, the averages of the dimensions in students' five-factor personality characteristics were close to each other, and the highest average was observed in the dimension of compliance.

According to the results of the analysis of variance performed on whether demographic variables made difference in the formation of personality characteristics; age and the number of siblings made difference in the 
dimension of openness to improvement; father's education made difference in the dimension of emotional balance; and the departments studied made difference in the dimension of extroversion. According to paired comparison analysis results, gender difference made difference in the dimensions of compliance and openness to improvement, and academic average made difference in the dimension of compliance.

According to the results of logistic regression, it was determined that the independent variables of gender, grade, and father's education, she/he does not talk a lot, she/he remains in the background, and she/he would be sad quickly, were the questions affecting the average (dependent variable) sixth step in the model.

Academic researches in the future can be carried out for different vocational school or faculty students. The effects of different demographic variables on five-factor personality can be analyzed by expanding or researches for their relationship status can be carried out. Furthermore, researches for the students' personality characteristics and professional expectations can be the subject field of another research. The effect of students' personality characteristics on extracurricular school activities can also be investigated.

\section{References}

Barlı, Ö. (2008). Davraniş bilimleri ve örgütlerde davraniş. Behavioral sciences and Behavior in Organizations. Erzurum: Aktif Yayinevi.

Costa, P. T. J., \& McCrae, R. R. (1991). Four ways five-factors are basic. Personality Índividual Differences, 13(6), 653-665.

Costa, P. T. J., \& McCrae, R. R. (1995). Domains and facets: Hierarchical personality assessment using the revised NEO personality inventory. Journal of Personality Assessment, 64(1), 21-50.

Gill, C. M., \& Hodgkinson, G. P. (2007). Development and validation of the Five-Factor Model Questionnaire (FFMQ): An adjectival-based personality inventory for use in occupational settings. Personnel Psychology, 60(3), 731-766.

Goldberg, L. R. (1992). The development of markers for the big-five factor structure. Psychological Assessment, 1(4), $26-42$.

Goldberg, L. R. (1993). The structure of phenotypic personality traits. American Psychologist, 48, 26-34.

Goldberg, L. R., Johnson, J. A., Eber, H. W., Hogan, R., Ashton, M. C., Cloninger, C. R., \& Gough, H. G. (2006). The international personality item pool and the future of public-domain personality measures. Journal of Research in Personality, 40, 84-96.

Goldberg, L. R. (1999). A broad-band width, public domain, personality inventory measuring the lower-level facets of several five-factor models. In I. Mervielde, I. Deary, F. de Fruyt, and F. Ostendorf (Eds.), Personality psychology in Europe (pp. 7-28). Tilburg, The Nether lands: Tilburg University Press.

Güvenç, B. (1972). İnsan ve Kültür. Türk Sosyal Bilimler Derneği Yayinlari. Ankara: Ayyildiz Matbaasi.

Hogan, R. (1991). Personality and personality measurement. Handbook of Industrial and Organizational Psychology, 2, 873-919.

Jia, H. H. (2008). Relationships between the big five personality dimensions and cyberloafing behavior. Doctoral Dissertation, Southern Illionis University Carbondale, Illionis.

Merdan, E. (2013). Beş Faktör Kişilik Kuramı ile İş Değerleri İlişkisinin İncelenmesi: Bankacılık Sektöründe Bir Araştırma. Gümüşhane Üniversitesi Sosyal Bilimler Elektronik Dergisi, 4(7), 140-159.

Mount, M. K., Barrick, M. R., Scullen, S. M., \& Rounds, J. (2005). Higher-order dimensions of the big five personality traits and the big six vocational interest types. Personal Psychology, 58, 447-478.

Mount, M., Ilies, R., \& Johnson, E. (2006). Relationship of personality traits and counterproductive work behaviours: The mediating effects of job satisfaction. Personnel Psychology, 59(3), 591-622.

Mc Adams, D. P. (1997). A conceptual history of personality psychology. In R. Hogan, J. Johnson, and S. Briggs (Eds.), Handbook of personality psychology (pp. 3-39). San Diego, CA: Academic Press.

Nelson, K. W. (2011). Motivation and personality: An examination of the big five personality trait factors and their relationship with sales performance in a non-cash incentive program. Doctoral Dissertation, Capella University, Minnesota.

Ökten, A. B., \& Cenkci, T. (2013). Beş faktör kişilik modeli ve örgütsel muhalefet arasindaki ilişki üzerine bir araştirma. Marmara Üniversitesi Öneri Dergisi, 10(39), 41-51.

Sarıtaş, A. (1997). Yönetimde kişilik faktörü. Eğitim Bilimleri Dergisi, 3(4), 527-548.

Somer, O., Korkmaz, M., \& Tatar, A. (2002). Beş faktör kişilik envanteri'nin geliştirilmesi-i: ölçek ve alt ölçeklerin oluşturulmasi. 
Türk Psikoloji Dergisi, 17(49), 21-33.

Soysal, A. (2008). Çalişma yaşaminda kişilik tipleri: Bir literatür taramasi (pp. 4-19). Çeiş Çimento Endüstrisi İşverenleri Sendikasi Yayin Organi. Retrieved from http://www.ceis.org.tr/dergiDocs/makale129.pdf

Tatlılıŏglu, K. (2014). Üniversite Öğrencilerinin Beş Faktör Kişilik Kurami’na Göre Kişilik Özellikleri Alt Boyutlarinin Bazi Değişkenlere Göre İncelenmesi. Tarih Okulu Dergisi (TOD), XVII, 939-971.

Tozkoparan, G. (2013). Beş faktör kişilik özelliklerinin çatişma yönetim tarzlarina etkisi: Yöneticiler üzerinde bir araştirma. Ekonomik ve Sosyal Araştırmalar Dergisi, 9(2), 189-231. 